\title{
Calcium Modulates the Rapid Kinetics of the Odorant-induced Cyclic AMP Signal in Rat Olfactory Cilia
}

\author{
Donna E. Jaworsky, ${ }^{1}$ Osamu Matsuzaki, ${ }^{1,3}$ Felice F. Borisy, ${ }^{1}$ and Gabriele V. Ronnett ${ }^{1,2}$ \\ Departments of ${ }^{1}$ Neuroscience and ${ }^{2}$ Neurology, Johns Hopkins University School of Medicine, Baltimore, Maryland 21205 - \\ 2185, and ${ }^{3}$ Asahi Chemical Company, Fuji City, Japan
}

\begin{abstract}
Although the CAMP and phosphoinositide (PI) second messenger systems are involved in olfactory signal transduction, aspects of their roles remain unclear. We have further examined the rapid kinetics of CAMP fluctuations in response to odorants in rat olfactory cilia isolated by calcium shock. Odorants cause a rapid and transient subsecond elevation of cAMP levels, as well as a more sustained signal lasting 5-10 sec. Basal CAMP levels demonstrate a biphasic calcium dependence; calcium enhanced both adenylyl cyclase (AC) and phosphodiesterase (PDE) activities. The odorantinduced CAMP response also demonstrated a biphasic dependence on calcium, with peak activity at $10 \mu \mathrm{M}$ free calcium. All odorants tested were found to stimulate CAMP accumulation, and the dose-response curves were multiphasic, with less stimulation seen at higher concentrations. Dose-response curves performed for isovaleric acid at two free calcium concentrations demonstrated that calcium can influence cellular responsiveness to odorants and may be involved with signal potentiation as well as desensitization.

[Key words: CAMP, olfaction, adenylyl cyclase, olfactory cilia, calcium, signal transduction]
\end{abstract}

Olfactory signal transduction, which occurs in the cilia of olfactory receptor neurons (ORNs), appears to proceed through the generation of cyclic adenosine $3^{\prime} 5^{\prime}$-monophosphate (cAMP) and inositol 1,4,5-trisphosphate ( $\operatorname{InsP}_{3}$ ) (Pace et al., 1985; Sklar et al., 1986; Boekhoff et al., 1990; Breer et al., 1990; Lowe and Gold, 1991; Ronnett et al., 1991b, 1993; Miyamoto et al., 1992). The membrane receptors that transduce the odorant stimuli are thought to be G-protein-coupled receptors that are members of a large multigene family (Buck and Axel, 1991; Buck, 1992). Recent evidence suggests that these two second messenger pathways are colocalized in sensory neurons (Cunningham et al., 1992), allowing for possible interactions between these cascades within a single cell. cAMP initiates the electrophysiological response by directly activating a nonspecific cation channel located in the plasma membrane of the sensory cilia (Nakamura

\footnotetext{
Received Dec. 6, 1993; revised May 13, 1994; accepted June 16, 1994.

We thank Drs. Solomon H. Snyder, Doron Lancet, Stuart Firestein, and KingWai Yau for helpful discussions and reading of this manuscript. G.V.R. is supported by grants from the McKnight Endowment Fund for Neuroscience, the Whitehall Foundation, the W. M. Keck Foundation, NIH/NIDA Grant R29DC00872-04, and International Flavors and Fragrances. O.M. is supported by a grant from Asahi Chemical Industry Co., Ltd.

Correspondence should be addressed to Gabriele V. Ronnett, Department of Neurology, Johns Hopkins University School of Medicine, 725 N. Wolfe Street, Baltimore, MD 21205-2185.

Copyright (C) 1995 Society for Neuroscience $0270-6474 / 95 / 150310-09 \$ 05.00 / 0$
}

and Gold, 1987; Firestein and Werblin, 1989; Dhallan et al., 1990; Ludwig et al., 1990; Lowe and Gold, 1991). Mechanisms by which InsP $P_{3}$ may contribute to the electrophysiological response in this system are not well defined, but may be mediated through Ins $_{3}$ receptors that have been localized to the ciliary surface membrane (Cunningham et al., 1992; Restrepo et al., 1990, 1992).

Although the participation of these two second messenger cascades in olfaction is generally accepted, aspects of their involvement remain unclear, and may be different across species. Initial studies demonstrated a robust odorant-sensitive adenylyl cyclase (AC) present in frog olfactory cilia isolated by calcium $\left(\mathrm{Ca}^{2+}\right)$ shock (Pace et al., 1985). More detailed characterization of this enzyme in rat cilia (Sklar et al., 1986) demonstrated that it was best stimulated by fruity, floral, and herbaceous odorants, while putrid odorants could not be shown to stimulate $\mathrm{AC}$ activity. Using rapid stop-flow techniques, Breer and collaborators (Boekhoff et al., 1990) found extremely rapid increases in cAMP levels by odorants in isolated rat olfactory cilia. Certain odorants stimulated cAMP production at concentrations as low as 0.1 $\mu \mathrm{M}$, while others had no effect. Calcium was found to inhibit the cAMP response. These results collectively suggested that cAMP mediates olfactory signaling for only a subset of odorants. This was in contrast to a large amount of electrophysiological data demonstrating that potentially all ORNs depolarize in response to cAMP (Menevse et al., 1977; Firestein and Werblin, 1987, 1989; Nakamura and Gold, 1987; Labarca and Bacigalupo, 1988; Firestein et al., 1991a,b; Zufall et al., 1991). To evaluate signaling in intact cells, several primary culture systems of rat ORNs have been developed (Farbman, 1977; Hirsch and Margolis, 1979; Hirsch and Margolis, 1981; Noble et al., 1984; Gonzales et al., 1985; Maue and Dionne, 1987; Calof and Chikaraishi, 1989; Pixley and Pun, 1990; Pixley, 1992). Using intact cells maintained in monolayer culture that were pretreated with staphylococcal $\alpha$-toxin (to introduce extremely small pores allowing for the introduction of radioligand), all odorants examined were found to stimulate $\mathrm{AC}$, with as little as $0.1 \mathrm{nM}$ odorant elevating enzyme activity (Ronnett et al., 199la,b). Responses for odorants were biphasic, with enhancement of $\mathrm{AC}$ disappearing at elevated concentrations.

Odorant-induced enhancement of InsP $\mathrm{P}_{3}$ levels was similarly demonstrated using a rapid stop-flow paradigm (Breer et al., 1990). It was found that those odorants that stimulated cAMP production appeared complementary to those that stimulated InsP $\mathrm{P}_{3}$ accumulation. On the other hand, using metabolic labeling of intact cells with ${ }^{3} \mathrm{H}$-myo-inositol, all odorants were found to stimulate phospholipase C (PLC) activity, as well as AC activity, suggesting that these second messenger cascades may not be 
complementary, but function simultaneously in odorant signaling (Ronnett et al., 1993). An increase in intraciliary $\mathrm{Ca}^{2+}$ concentrations as a result of the action of the $\mathrm{InsP}_{3}$ could modulate AC or PLC activities.

To examine these discrepancies, we have further studied the rapid odorant-induced cAMP response in isolated rat cilia. We demonstrate that all odorants tested affect cAMP accumulation. We have determined that $\mathrm{Ca}^{2+}$ is important in this response and can modulate the dose-response curve.

\section{Materials and Methods}

Materials. Tris(hydroxymethyl)aminomethane (Tris), Tris hydrochloride (Tris- $\mathrm{HCl})$, ethylene glycol-bis $\left(\beta\right.$-aminoethyl ether)- $N, N, N^{\prime}, N^{\prime}$-tetraacetic acid (EGTA), DL-dithiothreitol (DTT), adenosine 5 '-triphosphate, magnesium salt (Mg-ATP), guanosine 5 '-triphosphate (GTP), $3 \alpha, 7 \alpha, 12 \alpha$-trihydroxy-5 $\beta$-cholan-24-choleic acid, sodium salt (choleic acid), calcium chloride, and 3'-isobutyl-1-methylxanthine (IBMX) were purchased from Sigma Chemical Company (St. Louis, $\mathrm{MO}$ ). $\mathrm{NaCl}, \mathrm{MgCl}_{2}$, ethylenediaminetetraacetic acid, disodium salt (EDTA), anhydrous ether, and trichloroacetic acid (TCA) were purchased from J. T. Baker, Incorporated (Phillipsburg, NJ). 4-Morpholinpropansulfonic acid (MOPS) was obtained from Boehringer Mannheim (Germany). The chemical/ freeze quench apparatus, System 1000, was supplied by Update Instrument, Incorporated (Madison, WI), and the calcium electrode was supplied by Orion (Boston, MA). Adenosine 3',5'-cyclic phosphate (cAMP) was assayed by the Amersham ${ }^{125}$ I-labeled cAMP assay system (Amersham Corporation, Arlington Heights, IL). Isovaleric acid (IVA), 3,7dimethyl-2,6-octadienenitrile (citralva), and 2-isobutyl-3-methoxypyrazine (IBMP) were obtained from International Flavors and Fragrances (Union Beach, NJ).

Tissue preparation. Cilia were prepared from adult male rats (150$200 \mathrm{gm}$ ) according to the procedure of Sklar et al. (1986). Briefly, male Sprague-Dawley rats were killed by decapitation. Nasal turbinates were dissected, pooled, and washed in Kreb's Ringer's solution $(120 \mathrm{~mm}$ $\mathrm{NaCl}, 5 \mathrm{~mm} \mathrm{KCl}, 1.6 \mathrm{~mm} \mathrm{~K}_{2} \mathrm{HPO}_{4}, 25 \mathrm{~mm} \mathrm{NaHCO}_{3}, 7.4 \mathrm{~mm}$ glucose, $\mathrm{pH} 8.0$ ) at $4^{\circ} \mathrm{C}$. The tissue was centrifuged at $5,000 \times \mathrm{g}$ for $5 \mathrm{~min}$. The pellet was resuspended in $100 \mathrm{~mm}$ Tris $\mathrm{HCl}, \mathrm{pH} 8.0$. The bathing medium was supplemented with $\mathrm{CaCl}_{2}$ to a final concentration of $10 \mathrm{~mm}$ and agitated gently on an end-over-end shaker for $20 \mathrm{~min}$ at $4^{\circ} \mathrm{C}$. The deciliated epithelium was removed by centrifugation for 5 min at 1500 $\times g$. The supernatant containing the detached cilia was centrifuged for $10 \mathrm{~min}$ at $12,000 \times \mathrm{g}$ and the resulting pellet containing the isolated cilia was washed twice in $10 \mathrm{~mm}$ Tris- $\mathrm{HCl}, 3 \mathrm{~mm} \mathrm{MgCl}, 1 \mathrm{~mm}$ EDTA, $\mathrm{pH}$ 8.0. The final cilia pellet was resuspended in a small volume of 10 mм Tris- $\mathrm{HCl}, 3 \mathrm{~mm} \mathrm{MgCl}, 1$ mм EDTA, pH 8.0.

The concentrated rat cilia were aliquoted and stored at $-70^{\circ} \mathrm{C}$. No loss of activity was detected for up to 6 months. Protein concentrations of the final cilia preparations were measured according to the method of Lowry et al. (1951) using bovine scrum albumin as standard.

Activation of olfactory cilia. The chemical/freeze quench apparatus was used with three syringes to perform reactions in the millisecond range from $20 \mathrm{msec}$ to $500 \mathrm{msec}$. Longer time courses were performed manually. The first syringe contained cilia suspended in buffer that consisted of $10 \mathrm{~mm}$ Tris- $\mathrm{HCl}, 3 \mathrm{~mm} \mathrm{MgCl}_{2}$, and $10 \mathrm{~mm}$ EGTA. The second syringe held reaction mix containing $50 \mathrm{~mm}$ MOPS, $2.5 \mathrm{~mm}$ $\mathrm{MgCl}_{2}, 1.0 \mathrm{mM}$ DTT, $1.0 \mathrm{mM} \mathrm{Mg}$-ATP, $1.0 \mu \mathrm{M} \mathrm{GTP}$, and $0.05 \%$ cholic acid, pH 7.4, with or without odorant at appropriate concentrations. Odorants were prepared from a stock in an ethanol solution and diluted for use so that the final ethanol concentration was less than $0.1 \%$. Control samples were run at each time point and consisted of reaction mix containing the same ethanol concentration and calcium concentration without odorant. Data are presented relative to these controls, as endogenous cAMP lcvels in isolated rat chemosensory cilia vary from preparation to preparation. The final free $\mathrm{Ca}^{2+}$ concentration was determined by $\mathrm{Ca}^{2+}$ electrode. The third syringe contained $13.5 \%$ trichloroacetic acid (TCA) as a quench. The reaction was carried out by combining 1 part cilia to 4 parts reaction mix to 4 parts quench. For experiments requiring IBMX, cilia were preincubated with or without $0.5 \mathrm{~mm}$ IBMX, a phosphodiesterase inhibitor, for $30 \mathrm{~min}$. The protein concentration in the first syringe averaged $170 \mu \mathrm{g}$ per milliliter of cilia buffer, as determined by the method of Lowry et al. (1951). Cyclic AMP assays were performed on $10 \mu \mathrm{g}$ of protein. Quenched samples were collected on ice and spun $10 \mathrm{~min}$ in a microfuge at $4^{\circ} \mathrm{C}$. The supernatant was collected and then ether extracted four times with $3 \mathrm{ml}$ of anhydrous ether to remove TCA. Cyclic AMP was assayed with the Amersham ${ }^{125}$ I-labeled cAMP assay system.

Calcium. The free $\mathrm{Ca}^{2}$ in the reacting solution (cilia plus reaction mix) was measured by a $\mathrm{Ca}^{2+}$ electrode (Orion Instruments, Boston, MA). Titrations were performed with $\mathrm{Ca}^{2+}$ and EGTA to obtain free $\mathrm{Ca}^{2+}$ concentrations ranging from 0.01 to $100 \mu \mathrm{M}$.

\section{Results}

Odorant-induced changes in cAMP levels at subsecond and longer times

Previous experiments which investigated the odorant-induced cAMP response using a rapid stop-flow paradigm have demonstrated that cAMP increases in response to odorants, with a peak between 50 and $100 \mathrm{msec}$ (Boekhoff et al., 1990; Breer et al., 1990). A sustained signal that decays more slowly was seen, but reportedly only at high odorant concentrations (Breer et al., 1990). These results are in contrast to those obtained in whole cells, where odorants may stimulate AC activity for up to 15 $20 \mathrm{sec}$, depending upon the odorant (Ronnett et al., 1991b). To investigate these findings further, rapid stop-flow experiments were performed using rat olfactory cilia isolated by $\mathrm{Ca}^{2+}$ shock as described in Materials and Methods. Using a three syringe configuration, cilia contained in the first syringe were mixed for 20-500 msec with AC reaction mix containing the appropriate concentration of odorant, and the reaction was quenched with TCA. RIA was performed on an aliquot of each reaction. Exposure of cilia to the odorant citralva at a concentration of 0.1 $\mu \mathrm{M}$ resulted in increased cAMP levels as early as $50 \mathrm{msec}$, with peak levels at $100 \mathrm{msec}$ reaching as high as eightfold stimulation over basal levels, and declining rapidly thereafter (Fig. 1A). These results confirm those obtained by previous investigators (Boekhoff et al., 1990; Breer et al., 1990), although it was of interest that stimulation was seen at even lower odorant concentration, and the dose-response curves were multiphasic, not linear.

To investigate whether this subsecond signal was temporally the only fluctuation in cAMP levels in response to odorants, a second set of experiments was performed manually from 0 to $20 \mathrm{sec}$ of odorant exposure. As described in Materials and Methods, tubes containing cilia were mixed with reaction mix containing citralva at $0.1 \mu \mathrm{M}$ and quenched manually with TCA. A second peak of odorant-stimulated cAMP accumulation occurred, peaking by $5 \mathrm{sec}$ (Fig. $1 B$ ). Thus, in addition to the rapid response potent at lower odorant concentrations, a second robust peak of cAMP accumulation in response to odorants is seen in the seconds time range. These results appeared to concur in general with those obtained using whole cells (Ronnett et al., 1991b, 1993).

\section{Effect of $\mathrm{Ca}^{2+}$ on basal cAMP levels}

To determine whether free $\mathrm{Ca}^{2+}$ concentration may modulate the odorant-induced cAMP response at rapid times, the effect of varying $\mathrm{Ca}^{2+}$ concentrations on basal cAMP levels was examined. Previous studies (Boekhoff et al., 1990; Breer et al., 1990) have reportedly maintained reaction conditions at low free $\mathrm{Ca}^{2+}$. An olfactory AC has been cloned that is $\mathrm{Ca}^{2+}$ dependent (Bakalyar and Reed, 1990), and biochemical analysis reveals that $\mathrm{AC}$ activities in olfactory cilia are $\mathrm{Ca}^{2+}$ dependent (Choi et al., 1992). Additionally, several high-affinity phosphodiesterase activities are found in olfactory epithelium and localized to the ORNs, including both $\mathrm{Ca}^{2+}$-dependent and $\mathrm{Ca}^{2+}$ independent PDEs (Borisy et al., 1992). 

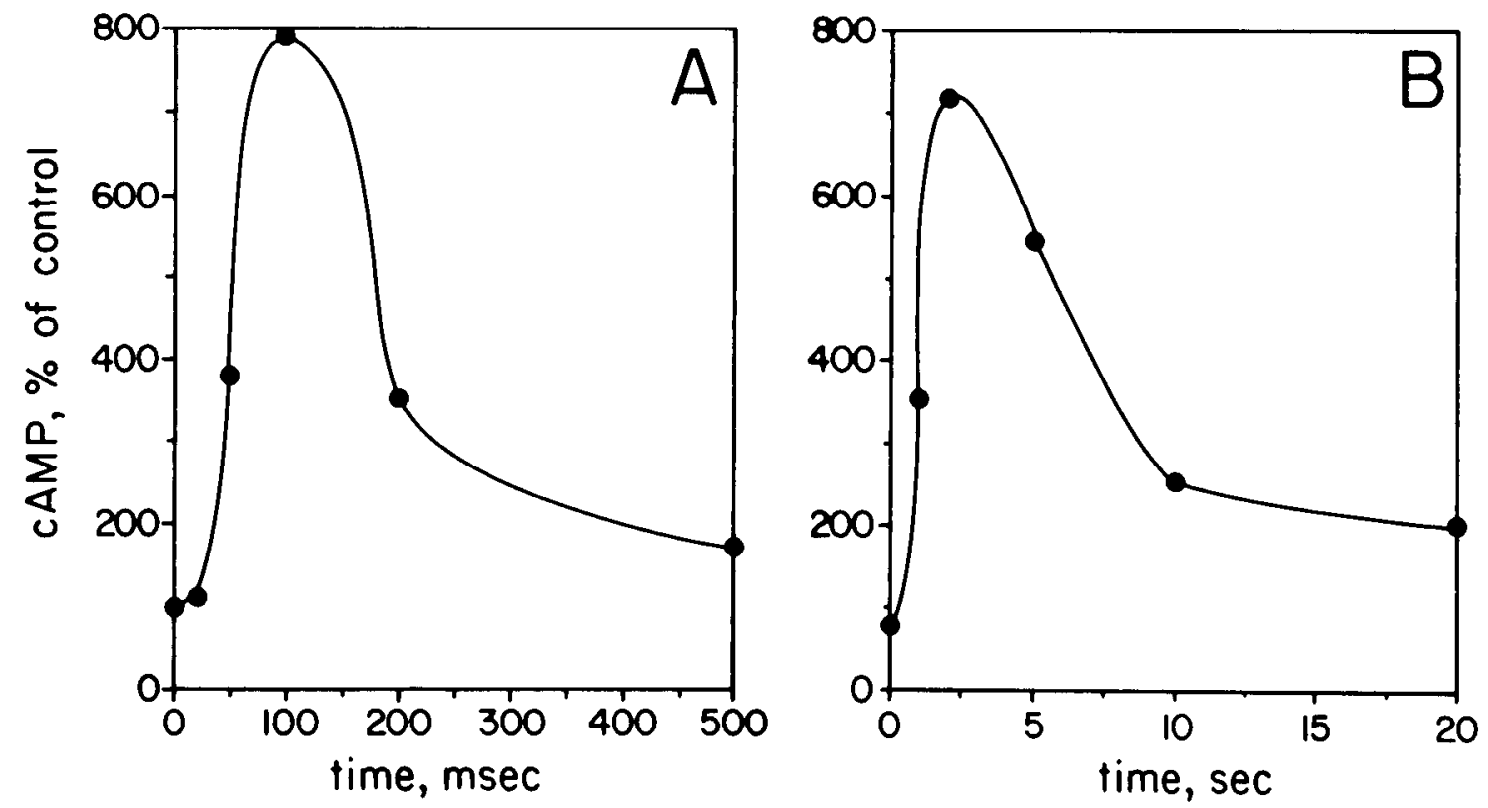

Figure 1. Effect of citralva on cAMP levels in rat olfactory cilia measured at subsecond and second times. Rat cilia isolated by $\mathrm{Ca}^{2+}$ shock were prepared as described in Materials and Methods. Cilia were incubated with reaction mix containing $0.1 \mu \mathrm{M}$ citralva and a free $\mathrm{Ca}^{2+}$ concentration of $10 \mu \mathrm{M}$, as determined by $\mathrm{Ca}^{2+}$ electrode. At each time point, duplicate samples were quenched with TCA as described in Materials and Methods and the concentration of cAMP determined by RIA. $A$, Determination of cAMP concentration at millisecond time points, performed using rapid stop-flow analysis. $B$, Determination of cAMP concentration at second time points, performed manually. Results are presented as percentage of basal, and are averages of duplicates representative of three separate determinations.

To determine the effects of $\mathrm{Ca}^{2+}$ on basal cAMP in levels in cilia, the olfactory cilia were subjected to rapid stop-flow conditions and mixed with reaction mix containing varying free $\mathrm{Ca}^{2+}$ from 0.01 to $100 \mu \mathrm{M}$. Cyclic AMP levels were measured at $100 \mathrm{msec}$. Although no specific inhibitor exists for $A C$, the relative contributions of $\mathrm{AC}$ or $\mathrm{PDE}$ activation by $\mathrm{Ca}^{2+}$ may be addressed by the use of IBMX, a potent phosphodiesterase inhibitor (Beavo, 1988). Cilia were preincubated for $30 \mathrm{~min}$ at room temperature with or without $0.5 \mathrm{mM}$ IBMX prior to the rapid mixing experiments. Comparing results at $100 \mathrm{msec}$, there is an overall increase in cAMP levels from $0.01 \mu \mathrm{M} \mathrm{Ca}^{2+}$ to 100 $\mu \mathrm{M} \mathrm{Ca}^{2+}$, from 12.2 pmol of cAMP per mg protein to $26 \mathrm{pmol}$ of cAMP per mg protein (Fig. $2 A$ ). From $10 \mu \mathrm{M} \mathrm{Ca}{ }^{2+}$ to $100 \mu \mathrm{M}$ $\mathrm{Ca}^{2+}$, cAMP levels decrease from $26 \mathrm{pmol}$ of cAMP per $\mathrm{mg}$ protein to $5.6 \mathrm{pmol} / \mathrm{mg}$ protein. This somewhat greater than twofold stimulation of cAMP levels by $\mathrm{Ca}^{2+}$ is consistent with the stimulation seen biochemically and in cloned expressed $\mathrm{AC}$ III (Bakalyar and Reed, 1990). Cilia preincubated with $0.5 \mathrm{~mm}$ IBMX revealed a different dosc-response curve (Fig. 2A). Cyclic AMP levels increased, as $\mathrm{Ca}^{2+}$ concentrations were increased, from $0.01 \mu \mathrm{M}$ to $50 \mu \mathrm{M}$, going from 14.2 pmol of CAMP per mg protein to $73.2 \mathrm{pmol}$ of cAMP per $\mathrm{mg}$ protein, with a slight decrease at higher $\mathrm{Ca}^{2+}$ concentrations. The disproportionate augmentation of cAMP levels with increasing $\mathrm{Ca}^{2+}$ seen when cilia were preincubated with IBMX suggests that a $\mathrm{Ca}^{2+}$-dependent phosphodiesterase is involved. When the PDEs are inhibited, a robust $\mathrm{Ca}^{2+}$-dependent $\mathrm{AC}$ response is revealed (Fig. $2 A)$.

Similar experiments were performed manually at $5 \mathrm{sec}$ (Fig. $2 B$ ). In the absence of IBMX, cAMP levels increased from 32 $\mathrm{pmol} / \mathrm{mg}$ protein at $0.01 \mu \mathrm{M}$ free $\mathrm{Ca}^{2+}$ to $75 \mathrm{pmol}$ of cAMP per mg protein at $10 \mu \mathrm{M}$ free $\mathrm{Ca}^{2+}$. Thereafter, cAMP levels decreased from 75 to $53 \mathrm{pmol} / \mathrm{mg}$ protein. At longer time points, therefore, there is a more robust stimulation of cAMP levels in the absence of IBMX than that seen at shorter time points. When cilia were preincubated with IBMX and then reacted in the presence of buffers containing varying $\mathrm{Ca}^{2+}$ levels, cAMP increased from $48 \mathrm{pmol} / \mathrm{mg}$ protein at $0.01 \mu \mathrm{M}$ free $\mathrm{Ca}^{2+}$ to 87 pmol of cAMP per mg protein at $10 \mu \mathrm{M}$ free $\mathrm{Ca}^{2+}$, and subsequently declined. At these longer time points, the $\mathrm{Ca}^{2+}$ doseresponse curves in the presence and absence of IBMX are parallel. The disproportionate enhancement of cAMP levels by IBMX at shorter time points (Fig. 2A) when compared to longer time points (Fig. $2 B$ ) suggests that a $\mathrm{Ca}^{2+}$-dependent PDE is important in modulating the subsecond signal, whereas this is not the case at longer time points. In both cases, however, the contribution to ambient cAMP levels by $\mathrm{AC}$ appears to be $\mathrm{Ca}^{2+}$ dependent. Based upon these dose-response curves, subsequent experiments were performed at $10 \mu \mathrm{M}$ free $\mathrm{Ca}^{2+}$, unless otherwise indicated.

\section{Effect of $\mathrm{Ca}^{2+}$ on odorant-stimulated cAMP levels}

Although $\mathrm{Ca}^{2+}$ can modulate basal cAMP levels, the effect of $\mathrm{Ca}^{2+}$ during odorant stimulation may be quite different. To study this, rapid stop-flow assays were performed on cilia exposed to reaction mix containing $0.1 \mu \mathrm{M}$ citralva at $0.1,10$, and $100 \mu \mathrm{M}$ free $\mathrm{Ca}^{2+}$. A time course from 0 to $500 \mathrm{msec}$ was performed under each of these conditions (Fig. 3). As in the case of basal cAMP levels, odorant-stimulated cAMP responses are affected by free $\mathrm{Ca}^{21}$, with maximal response at $10 \mu \mathrm{M}$ free $\mathrm{Ca}^{2+}$. Higher $\mathrm{Ca}^{2+}$ concentrations result in a diminished odorantstimulated peak. Thus, the concentration of free $\mathrm{Ca}^{2+}$ also appears to be important in determining basal as well as odorantstimulated cAMP levels.

\section{Generality of the odorant-induced cAMP response}

Although the second messenger systems cAMP and InsP $_{3}$ have been implicated in olfaction, conclusions differ as to whether 

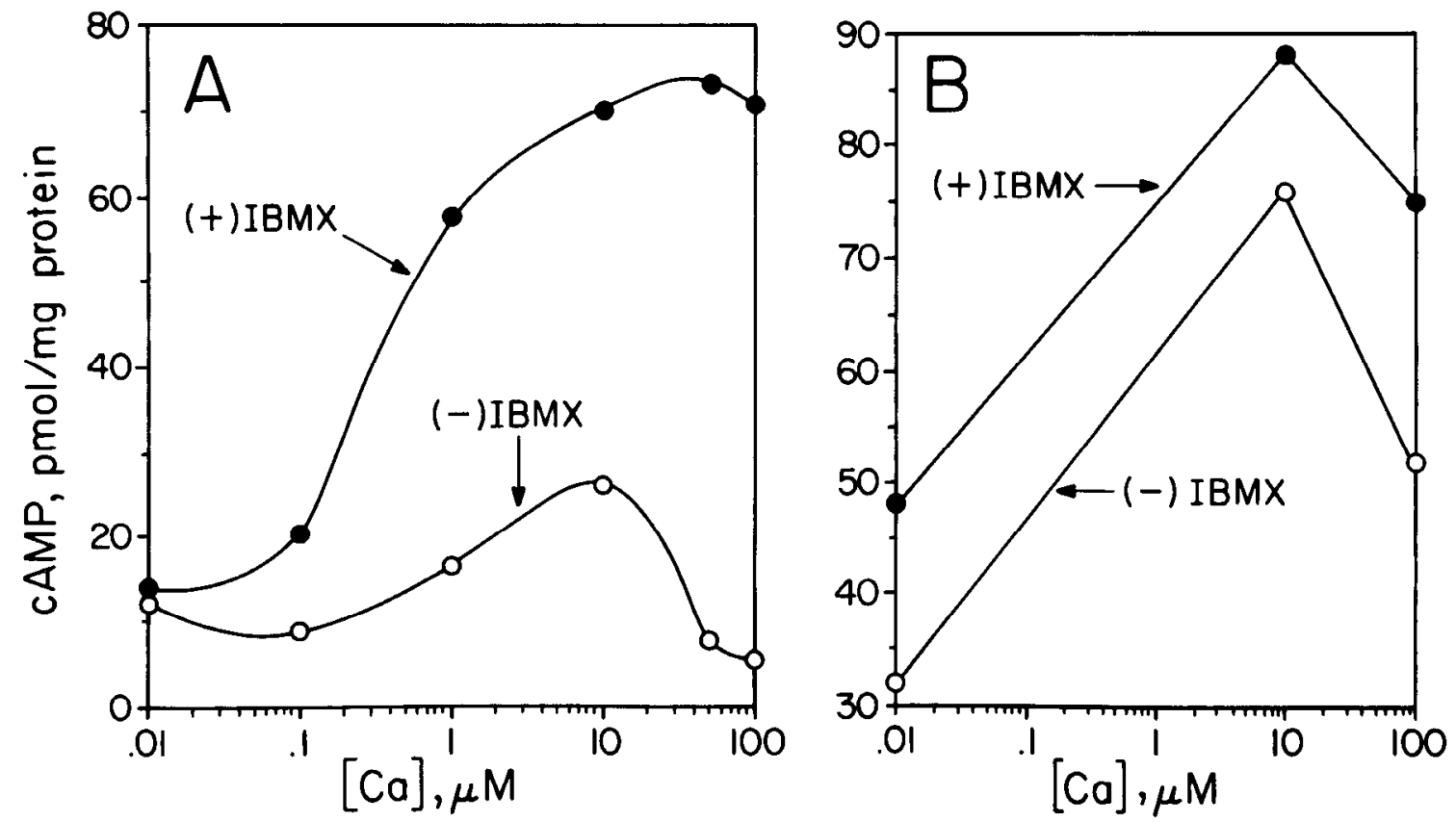

Figure 2. Effect of $\mathrm{Ca}^{2+}$ on cAMP levels in the presence and absence of IDMX. Olfactory cilia were prepared as described in Materials and Methods. Cilia were preincubated in the presence or absence of IBMX for 30 min prior to incubation with reaction mix containing varying Ca ${ }^{2+}$ concentrations. At zero time, cilia were mixed with reaction mix containing varying $\mathrm{Ca}^{2+}$ concentrations, from 0.01 to $100 \mu \mathrm{M} \mathrm{Ca}^{2+}$, and allowed to incubate for the designated time, at which the reactions were quenched. RIA was performed to determine cAMP levels as described in Materials and Methods. A, cAMP concentrations in reactions performed for $100 \mathrm{msec}$. $B$, cAMP concentrations from incubations performed for 5 sec. Results are presented as pmol of cAMP per mg protein. Data are averages of duplicates representative of three independent determinations.

all odorants stimulate both second messenger pathways, or whether odorants stimulate production of one or the other second messenger (Boekhoff et al., 1990; Breer et al., 1990; Ronnett et al., 1991b, 1993). To investigate this further, rapid stop-flow analyses were performed on cilia exposed to three odorants, citralva, isobutylmethoxypyrazine (IBMP), or isovaleric acid (IVA), using $10 \mu \mathrm{M}$ free $\mathrm{Ca}^{2+}$ in the reaction mix. These odorants were used because citralva has been shown to stimulate cAMP accumulation, whereas IBMP and IVA are not reported to act through cAMP in cilia using a rapid stop-flow paradigm, although they have been shown to stimulate $\mathrm{AC}$ in intact cells in culture (Ronnett et al., 1993). For initial screening, citralva was utilized at $10 \mu \mathrm{M}$, IBMP at $0.1 \mu \mathrm{M}$, and IVA at $0.1 \mu \mathrm{M}$, as these concentrations had previously given robust $\mathrm{AC}$ activation as measured in intact cells (Ronnett et al., 199 lb, 1993). As shown in Figure 4, all odorants augmented the accumulation of cAMP, although the levcl of stimulation varicd. Citralva, at this concentration, caused the greatest increase in cAMP levels, up to $510 \%$ of control (Fig. $4 A$ ). IBMP was nearly as effective, increasing cAMP levels to $482 \%$ of control (Fig. $4 B$ ). IVA was somewhat less effective, increasing cAMP levels to $364 \%$ of control (Fig. $4 C$ ), with a slightly earlier peak at $50 \mathrm{msec}$, as compared to $100 \mathrm{msec}$ for the other two odorants. Thus, those odorants previously not thought to stimulate cAMP accumulation indeed cause significant augmentation of cAMP levels.

Previous failure to demonstrate enhancement of cAMP levels in the presence of certain odorants may be due to several factors, one of which could be that the dose-response curves for cAMP levels at different odorant concentrations are nonlinear. Screening at one odorant concentration may miss a significant activation at lower or higher odorant concentrations. To investigate this, cilia were exposed to reaction mix containing odorants at

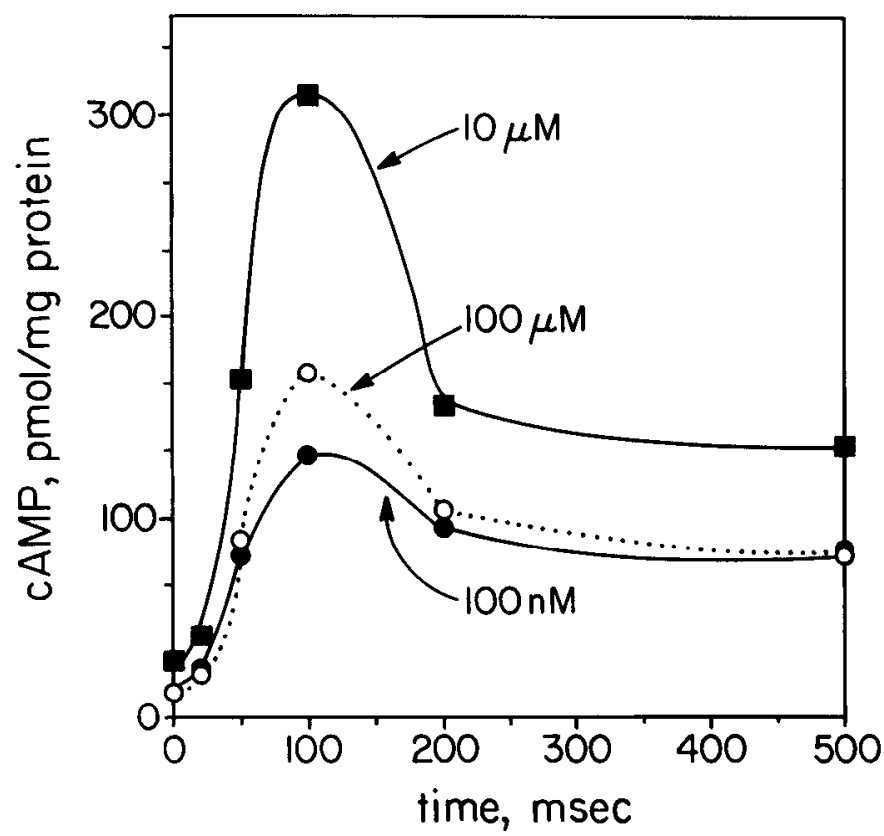

Figure 3. Effect of free $\mathrm{Ca}^{2+}$ concentration on citralva-induced elevation of cAMP levels measured in the subsecond time range. Rat cilia were isolated and reaction mixtures prepared as described in Materials and Methods. Using a rapid stop-flow device, cilia were incubated with reaction mixture containing $10 \mu \mathrm{M}$ citralva and free $\mathrm{Ca}^{2+}$ concentration from 0.1 to $100 \mu \mathrm{M}$. Reactions were allowed to proceed from 0 to 500 msec, at which time reactions were quenched by mixing the samples with TCA contained in a third syringe. Cyclic AMP levels were determined by RIA. Time courses are shown for citralva-induced changes in cAMP concentrations at $100 \mathrm{nM}$ free $\mathrm{Ca}^{2+}(0), 10 \mu \mathrm{M}$ free $\mathrm{Ca}^{2+}(\square)$, and $100 \mu \mathrm{M}$ free $\mathrm{Ca}^{2+}(\mathrm{O})$. Data shown are averages of duplicates representative of three determinations. 

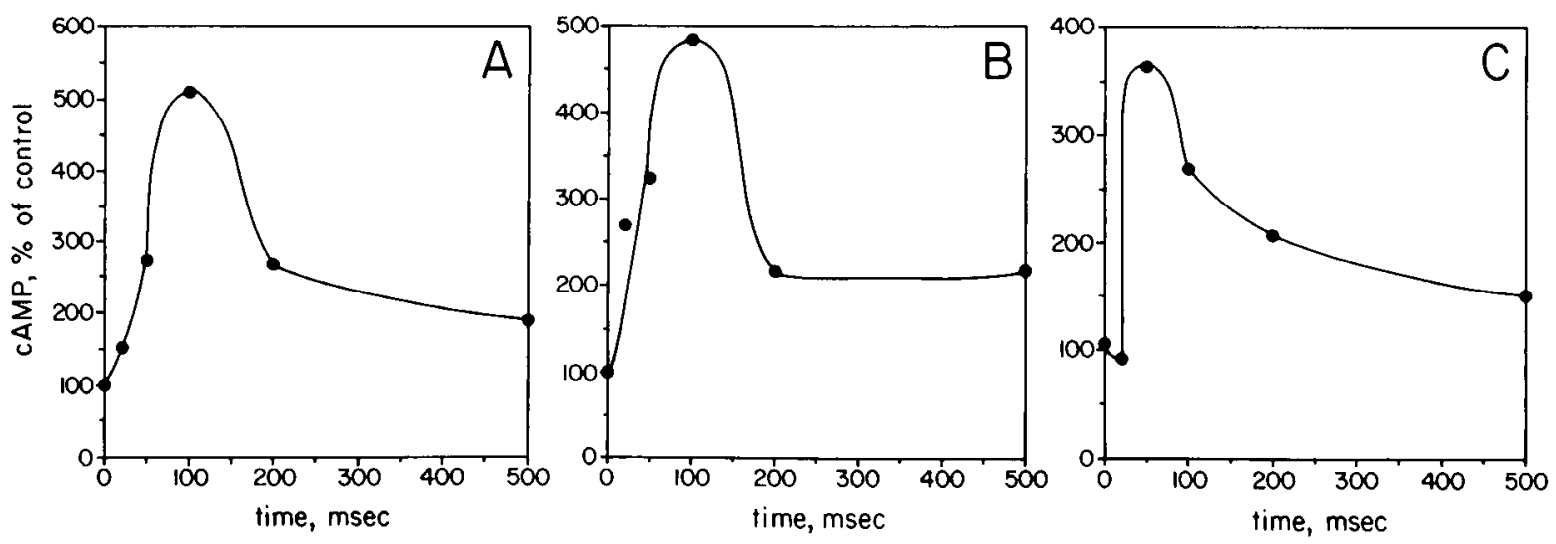

Figure 4. Time course of the effect of different odorants on cAMP concentrations in rat olfactory cilia measured in subsecond time course. Rat olfactory cilia were prepared as described in Materials and Methods. The reaction mix was maintained at $10 \mu \mathrm{M}$ free $\mathrm{Ca}^{2+}$, as determined by $\mathrm{Ca}^{2+}$ electrode. Cilia and reaction mix containing each odorant were mixed at zero time, and samples were quenched with TCA at the designated times. RIA was performed to assess cAMP levels at each time point. Time courses shown are for $10 \mu \mathrm{M}$ citralva $(A), 0.1 \mu \mathrm{M}$ IBMP $(B)$, and $0.1 \mu \mathrm{M}$ IVA (C). Control samples are run for each time point, consisting of duplicate samples except that reaction mix contained no odorant but buffer with the same final ethanol concentration as the solvent control. Data are presented as a percentage of these controls. Data shown are averages of duplicates representative of three experiments.

concentrations of $0.0001-100 \mu \mathrm{M}$ for $100 \mathrm{msec}$, at which time reaction was quenched as described in Materials and Methods. Samples were analyzed by RIA to determine cAMP levels. All reactions were carried out at $0.1 \mu \mathrm{M}$ free $\mathrm{Ca}^{2+}$ concentration. As shown in Figure 5, none of the three odorants investigated, citralva, IBMP, or IVA, demonstrated linear dose-response curves. Rather, they showed complicated multiphasic profiles, with significant peak activity occurring well below $1 \mu \mathrm{M}$ odorant concentration. The dose-response curves for citralva were multiphasic, with peaks occurring at $0.01 \mu \mathrm{M}$ and $10 \mu \mathrm{M}$ citralva (Fig. 5A). At $0.01 \mu \mathrm{M}$ citralva, cAMP levels were elevated $447 \%$ as compared to control, and at second peak were elevated to $264 \%$ of control (Fig. 5A). The dose-response curve for IBMP was also multiphasic, with peaks occurring at 0.1 and $10 \mu \mathrm{M}$ IBMP(Fig. 5B). Even at subnanomolar concentrations of IBMP, there was significant stimulation of cAMP accumulation, and the peak levels reached over $600 \%$ of control. Significant stimulation was also seen at $10 \mu \mathrm{M}$ IBMP, up to $370 \%$ of control. The dose-response curve for IVA (Fig. 5C) indicated a sharp peak at $0.001 \mu \mathrm{M}$ IVA, with cAMP levels reaching $515 \%$ of control. Higher concentrations maintained a significant elevation of CAMP accumulation, but there was no discrete secondary peak.

As mentioned, all odorants demonstrate a second peak of cAMP accumulation in the 5-15 sec time range. Cilia were mixed manually with reaction mix containing citralva at concentrations from 10 pM to $100 \mu \mathrm{M}$, for $5 \mathrm{sec}$, at which time the reactions were quenched with TCA. As can be seen in Figure 6 , the odorant response at $5 \mathrm{sec}$ at $0.1 \mu \mathrm{M}$ citralva is consistent with previous data obtained in whole-cell experiments measuring AC activity (Ronnett et al., 1991b, 1993). Again, doseresponse curves are multiphasic.
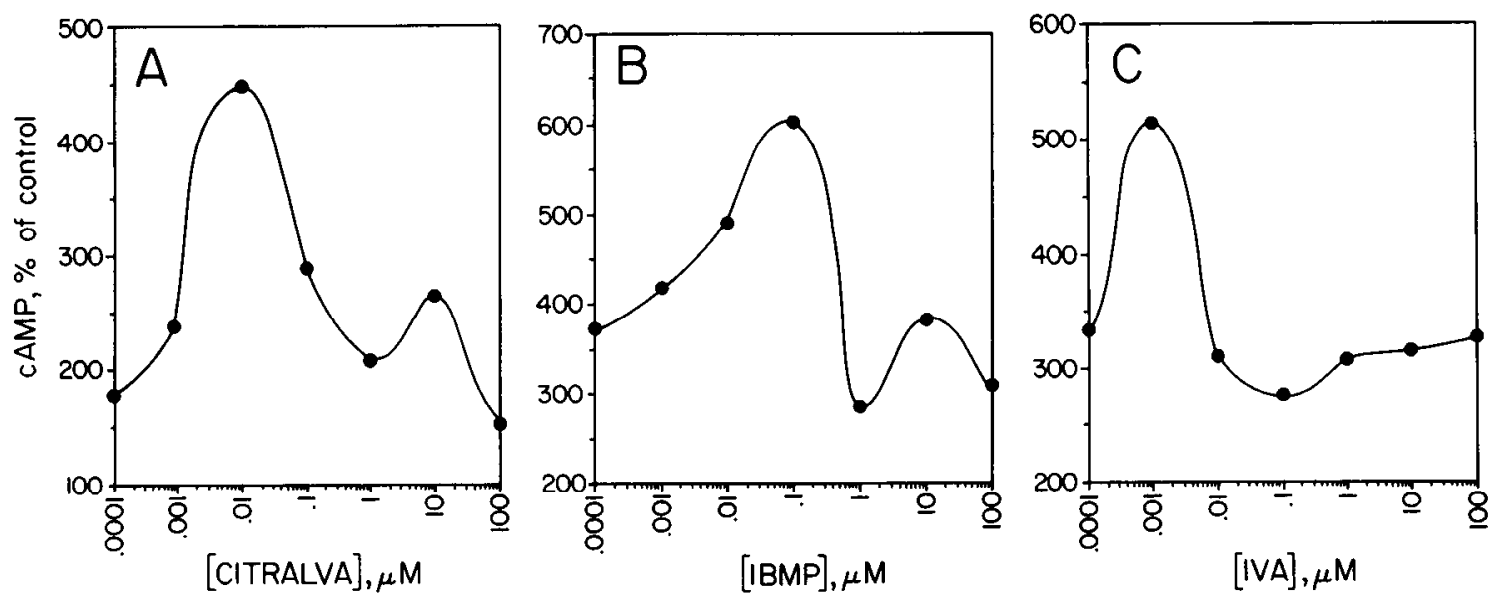

Figure 5. Effect of odorant concentration on cAMP levels in isolated rat cilia. Olfactory cilia, isolated and treated as described in Materials and Methods, were incubated with reaction mix containing varying concentrations of one of three different odorants for 100 msec utilizing a rapid stop-flow device. The reactions were quenched with TCA and RIA was performed to determine cAMP levels. All odorants were used at concentrations from 0.0001 to $100 \mu \mathrm{M}$, in log intervals. The three odorants tested were citralva $(A)$, IBMP $(B)$, and IVA $(C)$. Duplicate samples were run as controls and contained reaction mix with solvent minus odorant. Results are expressed as a percentage of this control value. Results shown are averages of duplicates from three separate experiments. 


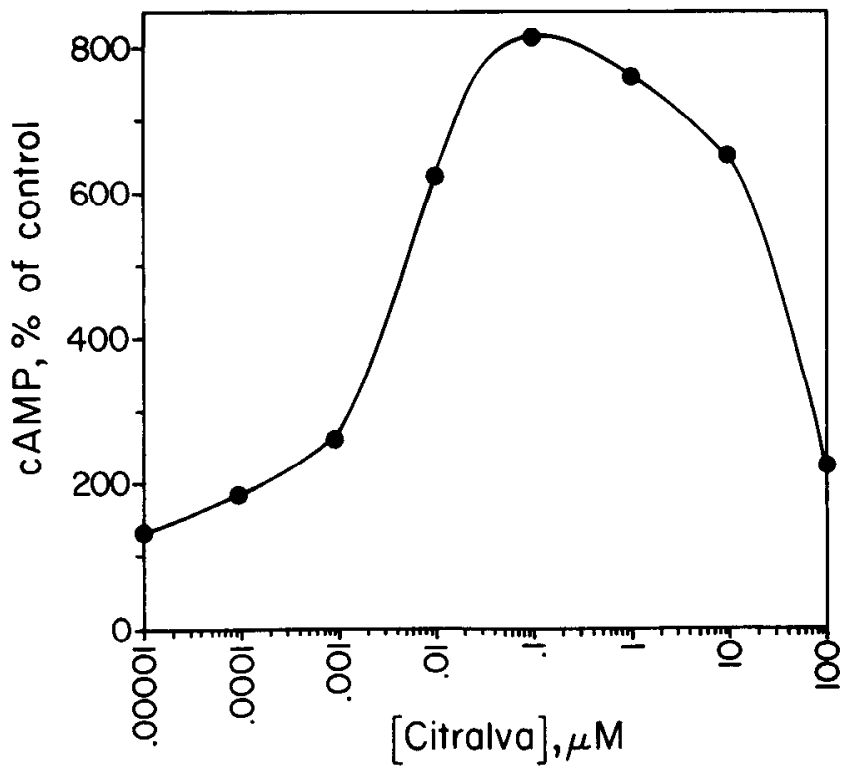

Figure 6. Effect of citralva concentration on cAMP levels in rat olfactory cilia measured at longer times. Rat olfactory cilia were prepared as described in Materials and Methods. Reaction mix was prepared as. described, and experiments were performed manually. At zero time, cilia were mixed with reaction mix containing varying amounts of citralva, from 0.00001 to $100 \mu \mathrm{M}$. The reaction was allowed to proceed for $5 \mathrm{sec}$, at which time the reaction was quenched with TCA and RIA was performed as described in Materials and Methods. Cyclic AMP levels are presented as percentage of control. Controls represent duplicate samples containing no odorant but rather buffer and the same concentration of ethanol in which odorants are dissolved. The data are averages of duplicates representative of threc separate experiments.

\section{Effect of $\mathrm{Ca}^{2+}$ on the dose-response curve for IVA}

These data suggest that $\mathrm{Ca}^{2+}$ may play an important role in modulating the odorant dose-response curve. Basal and odorant-stimulated cAMP levels are affected by free $\mathrm{Ca}^{2+}$ concentration. We have additionally shown that the dose-response curves for several odorants are nonlinear, having sharp multiphasic peaks. To assess whether the overall shape of the odorant dose-response curve could be modulated by free $\mathrm{Ca}^{2+}$, isolated cilia were exposed to reaction mix containing various concentrations of IVA, from 0.0001 to $100 \mu \mathrm{M}$, at $\mathrm{Ca}^{2+}$ concentrations of $0.1 \mu \mathrm{M}$ and $10 \mu \mathrm{M}$ free $\mathrm{Ca}^{2+}$. Several interesting differences are seen in the dose-response curves at these two $\mathrm{Ca}^{2+}$ concentrations (Fig. 7). First, the peak cAMP response shifts from 0.001 $\mu \mathrm{M}$ IVA at $0.1 \mu \mathrm{M}$ free $\mathrm{Ca}^{2+}$ to $0.01 \mu \mathrm{M}$ IVA at $10 \mu \mathrm{M}$ free $\mathrm{Ca}^{2+}$. This suggests that although at a certain odorant concentration, $0.01 \mu \mathrm{M}$ IVA in this case, the overall cAMP response may be heightened at elevated $\mathrm{Ca}^{2+}$ concentrations, the overall doseresponse curve shifts to the right, or potentially desensitizes at higher $\mathrm{Ca}^{2+}$ concentrations as well. Additionally, the overall responsiveness is higher at lower $\mathrm{Ca}^{2+}$ at the other odorant concentration. At higher free $\mathrm{Ca}^{2+}$, the peak is sharper, but the cAMP response at other odorant concentrations is significantly lower than at the lower concentration of free $\mathrm{Ca}^{2+}$.

\section{Discussion}

The principal findings of these experiments are that all odorants examined stimulate rapid cAMP accumulation, suggesting that cAMP is a final common messenger in signaling. The free $\mathrm{Ca}^{2+}$ concentration appears to be an important factor in modulating

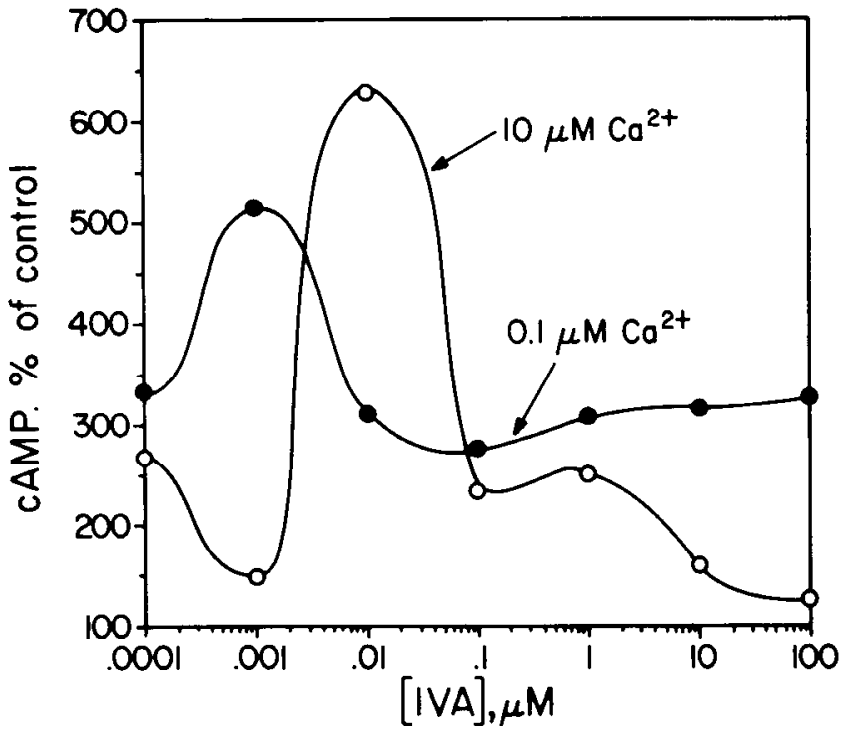

Figure 7. Effect of varying free $\mathrm{Ca}^{2+}$ concentration upon the IVA doseresponse curve. Cilia, prepared as described in Materials and Methods, were mixed with reaction mix containing $0.1 \mu \mathrm{M} \mathrm{Ca}^{2+}(\bullet)$ or $10 \mu \mathrm{M}$ free $\mathrm{Ca}^{2+}(\mathrm{O})$, and IVA concentrations ranged from 0.0001 to $100 \mu \mathrm{M}$. Samples were allowed to react for $100 \mathrm{msec}$, using a rapid stop-flow device, at which point samples were quenched with TCA and processed for RIA as described in Materials and Methods. As a control, duplicate samples were prepared for cach calcium concentration without odorant but with the same concentration of ethanol as used for the odorants. Data are presented as percentage of control, and represent averages of duplicates representative of three experiments.

this response. In whole-cell experiments, all odorants tested appeared to act via both second messenger systems (Ronnett et al., 1991, 1993), whereas previous experiments in isolated cilia suggested that any individual odorant utilized one or the other second messenger pathway (Boekhoff et al., 1990; Breer et al., 1990).

To clarify whether or not all odorants could elicit a cAMP signal, rapid stop-flow experiments were performed utilizing isolated rat olfactory cilia. In initial screening using citralva, we were able to corroborate the findings of other investigators (Boekhoff et al., 1990), demonstrating a rapid and transient elevation of CAMP in response to this odorant. Previous studies demonstrated a more sustained response only at extremely high odorant concentrations. Here, we show that even at low concentrations of odorant, there is in addition a more sustained accumulation of cAMP. These concentrations approach detection thresholds for aerosolized odorants, and are well within the range of odorant concentrations that give electrophysiological responses (Firestein and Werblin, 1987, 1989; Nakamura and Gold, 1987; Firestein et al., 199 la,b). An exact correlation between concentrations used in biochemical assays and in electrophysiological experiments is difficult due to procedural differences. In an attempt to resolve the apparent discrepancy between the time course of the sensory generator current in the presence of sustained odorant exposure (which can last 7-10 sec) and the transient elevation of the cAMP response initially reported (Boekhoff et al., 1990), Firestein and collaborators studied the gating kinetics of the olfactory channel and demonstrated that the overall slow channel-gating kinetics could perhaps account for these differences, as channel activity outlasted a cyclic nucleotide pulse for several hundred milliseconds 
(Zufall et al., 1993). Using caged cAMP and rat olfactory receptor neurons, Lowe and Gold (1993) demonstrated that the channel-gating kinetics do not determine the time course of the transduction current. The current generated by odorant exposure is much longer than that induced by flash photolysis of caged cAMP, suggesting that in mammals the $A C$ response is more prolonged. A more prolonged cAMP response of 5--10 sec fits with electrophysiological data on the time course of the sensory generator current and with data previously obtained by directly assaying $\mathrm{AC}$ activity in ORN culture monolayers (Ronnett et al., 1993, 1991b).

A number of differences in experimental variables may account for the discrepancies with previous investigations, that is, whether all odorants can stimulate cAMP production or whether different odorants use different second messenger systems. A factor that could be important is the ambient $\mathrm{Ca}^{2+}$ concentration used. To clarify the role of $\mathrm{Ca}^{2+}$ in this response, initial studies were done on basal cAMP levels subjected to rapid stop-flow analysis at varying $\mathrm{Ca}^{2+}$ concentrations in the presence or absence of IBMX. At both subsecond and 5 sec time points, $\mathrm{Ca}^{2+}$ stimulated the accumulation of cAMP. In the subsecond time range, this accumulation was disproportionately enhanced in the presence of IBMX at higher concentrations of $\mathrm{Ca}^{2+}$, suggesting that a $\mathrm{Ca}^{2+}$-dependent PDE is quite active at the subsecond time range, much more so than at longer time points. In addition, these results demonstrate that the $\mathrm{AC}$ activity appears to be $\mathrm{Ca}^{2+}$ dependent. A similar dependency on $\mathrm{Ca}^{2+}$ was found for the odorant-dependent cAMP response, with a peak effect seen at $10 \mu \mathrm{M}$ free $\mathrm{Ca}^{2+}$. Previous studies (Sklar et al., 1986) used only millimolar $\mathrm{Ca}^{2+}$ concentrations. At these high concentrations, inhibition is indecd scen in both intact cells (Ronnett et al., 1991b) and in isolated cilia, as shown here. Previous stop-flow experiments utilized extremely low $\mathrm{Ca}^{2+}(10-$ $20 \mathrm{nM}$ ); failure to see enhanced accumulation of cAMP with some odorants could be because intermediate $\mathrm{Ca}^{2+}$ concentrations were not used. At longer time points, other investigators have demonstrated a $\mathrm{Ca}^{2+}$ dependence using intermediate $\mathrm{Ca}^{2+}$ concentrations (Anholt and Rivers, 1990). Postulating that the presence of $\mathrm{Ca}^{2+}$ may be crucial in demonstrating the odorantinduced cAMP response for a number of odorants, dose-response curves were performed for citralva, as well as odorants previously thought to activate the Ins $\mathrm{P}_{3}$ but not the cAMP second messenger pathways, such as IVA. Utilizing $10 \mu_{\mathrm{M} \mathrm{Ca}} \mathrm{Ca}^{2+}$ in the reaction mix, all odorants were found to stimulate cAMP accumulation with multiphasic dose-response curves similar to, but not identical to, those observed in primary cultures of ORNs (Ronnett et al., 1991b, 1993). When compared to data obtained in primary cultures of ORNs using $\alpha$-toxin treatment to permeabilize cells to permit in situ assay of AC activities, similar multiphasic dose-response curves were obtained. However, the peaks of these curves differ by up to an order of magnitude from the curves obtained using the rapid stop-flow analysis. This may be due in part to the fact that in previous studies AC was assayed, whereas in this case cAMP levels are measured. However, in both cases, dose-response curves are nonlinear and multiphasic, with peak responses occurring at relatively low odorant concentrations. A similar multiphasic dose-response curve was seen when reactions were performed for $5 \mathrm{sec}$, indicating that both the subsecond and the second cAMP peaks demonstrate dose dependency and may be physiologically relevant.

A role for $\mathrm{Ca}^{2+}$ in olfaction is suggested by many studies (Getchell, 1986; Nakamura and Gold, 1987; Winegar et al.,
1988; Suzuki, 1989; Anholt and Rivers, 1990; Kurahashi and Shibuya, 1990; Restrepo et al., 1992; Kurahashi and Yau, 1993). Conflicts regarding the exact nature of $\mathrm{Ca}^{2+}$ involvement may be due to methodologic or interspecies differences. Most information available is from electrophysiological studies. In the lamprey, Suzuki showed that $\mathrm{Ca}^{2+}$ channel blockers inhibited spike responses (Suzuki, 1989). However, Nakamura and Gold demonstrated that rectification is abolished in the absence of divalent cations, suggesting a voltage-dependent channel blocking effect (Nakamura and Gold, 1987). Using whole-cell patchclamp techniques, Kurahashi and Shibuya observed an activation of the odorant-induced conductance only when the external medium contained $\mathrm{Ca}^{2+}$ (Kurahashi and Shibuya, 1990). However, single-channel recordings performed on isolated salamander ORNs showed no voltage dependence in divalent cation-free buffer (Leveteau et al., 1989). Kramer and Sigelbaum (1992) have demonstrated that $\mathrm{Ca}^{2+}$ inhibits the cyclic nucleotidegated channels by shifting the dose-response curves via cAMP levels without altering the maximum response. As they have no evidence for direct interaction of $\mathrm{Ca}^{2+}$ on the channel, they postulate that a regulatory $\mathrm{Ca}^{2+}$ binding protein is involved. $\mathrm{Ca}^{2+}$ has also been shown to induce the opening of the $\mathrm{Ca}^{2+}$. activated potassium channel. In a recent study by Chen and Yau (1994), $\mathrm{Ca}^{2+}$ reduced the apparent affinity of the cyclic nucleotide-gated channel for cAMP by up to 20 -fold in the presence of calmodulin. In several systems, $\mathrm{Ca}^{2+}$ has been found to activate a chloride channel (Kurahashi and Yau, 1993).

Relatively fewer experiments addressing these questions biochemically have been performed. The cloned expressed type III $\mathrm{AC}$ appears to have a $\mathrm{Ca}^{2+}$ dependence (Bakalyar and Reed, 1990). These observations fit with biochemical determinations, using isolated olfactory epithelium, that there exists at least one AC activity that is $\mathrm{Ca}^{2+}$ dependent (Choi et al., 1992). In addition, a novel high-affinity $\mathrm{Ca}^{2+} /$ calmodulin-dependent PDE activity has been described in olfactory epithelium and localized to the ORNs (Borisy et al., 1992). Additionally, high levels of calmodulin have been demonstrated in olfactory tissues (Anholt and Rivers, 1990; Borisy et al., 1992). Initial observations on the odorant-induced cAMP response suggested that $\mathrm{Ca}^{2+}$ may inhibit the response (Sklar et al., 1986), although these experiments were performed in isolated cilia at longer time points, which may have reflected interactions with desensitized receptors. In $\alpha$-toxin-permeabilized monolayer cultures on ORNs, $\mathrm{Ca}^{2+}$ augmented the odorant-induced activation of AC(Ronnett et al., 1991b, 1993). Utilizing the rapid stop-flow paradigm, we now demonstrate that this effect is similar at both subsecond and second time intervals.

Additionally, the dose-response curves, shown here for IVA, are modulated by free $\mathrm{Ca}^{2+}$ concentration. At higher $\mathrm{Ca}^{2+}$ concentrations the dose-response curve is shifted to the right, suggesting an element of desensitization decreases in a biological response over time despite the continued presence of a stimulus (Sibley et al., 1987). However, the effect of $\mathrm{Ca}^{2+}$ does not appear to involve only an element of desensitization. At the higher $\mathrm{Ca}^{2+}$ concentration, the peak cAMP response to IVA is actually higher in absolute magnitude at the higher $\mathrm{Ca}^{2+}$ concentration; this suggests a feedforward mechanism, or an increase in biological response due to increasing $\mathrm{Ca}^{2+}$. The complex changes seen in cAMP levels in response to odorants at two different $\mathrm{Ca}^{2+}$ concentrations may be due to differential effects of $\mathrm{Ca}^{2+}$ on AC and PDE activities, such that the ambient cAMP concentration may be quite dynamically regulated. Although there 
is no evidence for a direct effect of odorants on PDE activities, odorants may indirectly modulate PDE by causing a change in free $\mathrm{Ca}^{2+}$ levels, which can therefore indirectly modulate PDE activity.

The free $\mathrm{Ca}^{2+}$ concentration in cilia may be elevated during odorant exposure by one of several mechanisms. A cell surface Ins $\mathrm{P}_{3}$ receptor may allow the influx of $\mathrm{Ca}^{2+}$ from extracellular sourccs (Cunningham et al., 1992). On the other hand, $\mathrm{Ca}^{2+}$ may enter through the cyclic nucleotide-gated channel or via other mechanisms. Free $\mathrm{Ca}^{2+}$ concentration has been reported to increase in isolated ORNs after odorant exposure (Restrepo and Boyle, 1991; Hirono et al., 1992). In these studies using the fura-2, free calcium (measured over an approximately $100 \mu \mathrm{m}^{2}$ area) changes from an average concentration of $20-50 \mathrm{nM}$ to 150-250 nM with odorants. This gives rise to the possibility of quite robust elevations in free calcium in the micromolar range when considering extremely small areas such as the olfactory cilia. An additional limiting factor in detecting higher-thanmicromolar increases in free $\mathrm{Ca}^{2+}$ is that the $K_{\mathrm{m}}$ of fura-2 limits its sensitivity at higher calcium concentrations. Using fluo-3, Dulon and collaborators (Dulon et al., 1990) have shown that micromolar free calcium levels are achieved in isolated cochlear outer hair cells. Thus, the cAMP response may be augmented at certain concentrations of odorant as intracellular free $\mathrm{Ca}^{2+}$ is elevated. At other odorant concentrations, $\mathrm{Ca}^{2+}$ may cause the odorant-induced cAMP signal to desensitize. Shown here for IVA, for example, cilia may initially be quite responsive to 0.001 $\mu \mathrm{M}$ IVA, whereas at higher $\mathrm{Ca}^{2+}$ concentration, responsiveness at this odorant concentration is dampened. Calcium may have an affect on olfactory signal transduction at multiple levels. Thus, $\mathrm{Ca}^{2+}$ may affect the cyclic nucleotide-gated channel, as well as AC and PDE activities, ultimately to modulate ambient cAMP levels in the ORNs.

In the present study, all odorants tested significantly augment cAMP levels with complicated dose-response curves. Previous inability to detect a cAMP response for such odorants as IBMP and IVA may in fact be due to an underestimation of the importance of $\mathrm{Ca}^{2+}$ in eliciting the reaction. The results presented in this article support those results previously found in the assay of AC in intact ORNs, that all odorants stimulate cAMP production (Ronnett et al., 1991b, 1993). The ability of the same odorant to modulate cAMP as well as Ins $\mathrm{P}_{3}$ levels suggests intriguing possibilities for fine tuning of the olfactory response, depending upon the relative activation of these two pathways. In the lobster, amino acids differentially affect both pathways, with excitatory currents carried by $\operatorname{Ins}_{3}$, whereas inhibitory currents involve cAMP, thus providing a mcchanism for finc tuning of the response (Ache et al., 1993). Frings (1993) has demonstrated an augmentation of the odorant response in frogs in the presence of phorbol dibutyrate, an activator of protein kinase $\mathrm{C}$. In this system, $\mathrm{Ca}^{2+}$ caused sensitization of $\mathrm{AC}$ to stimulation by forskolin, suggesting possible cross talk of the cAMP and Ins $\mathrm{P}_{3}$ pathways. In primary cultures of ORNs, enhancement of InsP ${ }_{3}$ levels has been shown to enhance AC activity (G. V. Ronnett, unpublished observations). Thus, the precise mechanism as to how these two signal pathways interact may vary, depending on species.

Although olfactory cilia do not contain organelles known to act as repositories for $\mathrm{Ca}^{2+}$ (Menco, 1984, 1985a,b), abundant free $\mathrm{Ca}^{2+}$ exists in the extracellular milieu (Joshi et al., 1987), which may be made available to modulate ciliary enzyme function. Results in several species suggest that olfactory cilia may contain surface membrane $\mathrm{InSP}_{3}$ receptors capable of allowing entry of $\mathrm{Ca}^{2+}$ into the cilium (Cunningham et al., 1992; Fadool and Ache, 1992; Restrepo et al., 1992). Recent immunohistochemical and immunoelectron microscopic studies demonstrate the presence of an InsP $\mathrm{P}_{3}$ receptor on the ciliary surface (Ronnett et al., 1993). This receptor has many of the characteristics of the cerebellar receptor, including relative mobility on polyacrylamide gels consistent with the molecular wcight of $240,000 \mathrm{Da}$ and a binding affinity for Ins $\mathrm{P}_{3}$ in the range of cerebellar InsP receptor. Thus, $\mathrm{Ca}^{2+}$ could be made readily available to ciliary $\mathrm{AC}$ and $\mathrm{PDE}$, suggesting that $\mathrm{Ca}^{2+}$ may be physiologically relevant in modulating these enzyme activities in an odorant-dependent manner.

\section{References}

Ache B, Hatt H, Breer H, Boekoff I, Zufall F (1993) Biochemical and physiological evidence for dual transduction pathways in lobster olfactory receptor neurons. A Chem S 18:48.

Anholt RRH, Rivers AM (1990) Olfactory transduction: cross-talk between second-messenger systems. Biochemistry 29:4049-4054.

Bakalyar HA, Reed RR (1990) Identification of a specialized adenylyl cyclase that may mediate odorant detection. Science 250:1403-1406.

Beavo JA (1988) Multiple isozymes of cyclic nucleotide phosphodiesterase. Adv Second Messenger Res 22:1-38.

Boekhoff I, Tareilus E, Strotmann J, Breer H (1990) Rapid activation of alternative second messenger pathways in olfactory cilia from rats by different odorants. EMBO J 9:2453-2458.

Borisy FF, Ronnett GV, Cunningham AM, Juilfs D, Beavo J, Snyder SH (1992) Calcium/calmodulin activated phosphodiesterase expressed in olfactory receptor neurons. J Neurosci 12:915-923.

Borisy FF, Hwang PN, Ronnett GV, Snyder SH (1993) High affinity cyclic AMP phosphodiesterase and adenosine localized in sensory organs. Brain Res 610:199-207.

Breer H, Boekhoff I, Tareilus E (1990) Rapid kinetics of second messenger formation in olfactory transduction. Nature 345:65-68.

Buck LB (1992) The olfactory multigene family. Curr Biol 2:467-473.

Buck L, Axel R (1991) A novel multigene family may encode odorant receptors: a molecular basis for odor recognition. Cell 65:175-187.

Calof AL, Chikaraishi DM (1989) Analysis of neurogenesis in a mammalian neuroepithelium: proliferation and differentiation of an olfactory neuron precursor in vitro. Neuron 3:115-127.

Chen T-Y, Yau K-W (1994) Direct modulation by $\mathrm{Ca}^{2+}$-calmodulin of cyclic nucleotide-activated channel of rat olfactory receptor neurons. Nature, in press.

Choi E-J, Xia Z, Storm DR (1992) Stimulation of the type III olfactory adenylyl cyclase by calcium and calmodulin. Biochemistry 31:64926498.

Cunningham AM, Ryugo D, Sharp A, Reed RR, Snyder SH, Ronnett GV (1993) Neuronal inositol 1,4,5-trisphosphate receptor localized to the plasma membrane of olfactory cilia. Neuroscience 57:339-352.

Dhallan RS, Yau KW, Schrader KA, Reed RA (1990) Primary structure and functional expression of a cyclic nucleotide-activated channel from olfactory neurones. Nature 347:184-187.

Dulon D, Zajic G, Schacht J (1990) Increasing intracellular free calcium induces circumferential contractions in isolated cochlear outer hair cells. J Neurosci 10:1388-1397.

Fadool DA, Ache BW (1992) Plasma membrane inositol 1,4,5-trisphosphate-activated channels mediate signal transduction in lobster olfactory receptor neurons. Neuron 9:907-918.

Farbman Albert I (1977) Differentiation of olfactory receptor cells in organ culture. Anat Rec 189:187-199.

Firestein S, Werblin FS (1987) Gated currents in isolated olfactory receptor neurons of the larval tiger salamander. Proc Natl Acad Sci USA 84:6292-6296.

Firestein S, Werblin FS (1989) Odor-induced membrane currents in vertebrate olfactory receptor neurons. Science 244:79-82.

Firestein S, Darrow B, Shepherd GM (199la) Activation of the sensory current in salamander olfactory receptor neurons depends on a $G$ protein-mediated cAMP second messenger system. Neuron 6:825835.

Firestein S, Zufall F, Shepherd GM (1991b) Single odor-sensitive 
channels in olfactory receptor neurons are also gated by cyclic nucleotides. J Neurosci 11:3565-3572.

Frings S (1993) Protein kinase C sensitizes olfactory adenylate cyclase. J Gen Physiol 101:183-205.

Getchell TV (1986) Functional properties of vertebrate olfactory receptor neurons. Physiol Rev 66:772-818.

Gonzales F, Farbman AI, Gesteland RC (1985) Cell and explant culture of olfactory chemoreceptor cells. Neuroscience 14:77-90.

Hirono J, Sato T, Tonoike M, Takebayashi M (1992) Simultaneous recording of [calcium $2+$ li increases in isolated olfactory receptor neurons retaining their original spatial relationship in intact tissue. $J$ Neurosci Methods 42:185-194.

Hirsch JD, Margolis FL (1979) Cell suspensions from rat olfactory neuroepithelium: biochemical and histochemical characterization. Brain Res 161:277-291.

Hirsch JD, Margolis FL (1981) Isolation, separation, and analysis of cells from olfactory epithelium. Biochem Taste Olfact 311-332.

Joshi H, Getchell ML, Zielinski B, Getchell TV (1987) Spectrophotometric determination of cation concentrations in olfactory mucous. Neurosci Lett 82:321-326.

Kramer RH, Siegelbaum SA (1992) Intracellular $\mathrm{Ca}^{2+}$ regulates the sensitivity of cyclic nucleotide-gated channels in olfactory receptor neurons. Neuron 9:897-906.

Kurahashi T, Shibuya T (1990) $\mathrm{Ca}^{2+}$-dependent adaptive properties in the solitary olfactory receptor cell of the newt. Brain Res 515:261268.

Kurahashi T, Yau K-W (1993) Co-existence of cationic and chloride components in odorant-induced current of vertebrate olfactory receptor cells. Nature 363:71-74.

Leveteau J, Andriason I, Trotier D, MacLeod P (1989) Role of divalent cations in EOG generation. Chem Senses 14:611-620.

Lowe G, Gold GH (1991) The spatial distributions of odorant sensitivity and odorant-induced currents in salamander olfactory receptor cells. J Physiol (Lond) 442:147-168.

Lowe G, Gold GH (1993) Nonlinear amplification by calcium-dependent chloride channels in olfactory receptor cells. Nature 366:283286.

Lowry OH, Rosebrough NJ, Farr AL, Randall RJ (1951) Protein measurement with the folin reagent. J Biol Chem 193:265-275.

Ludwig J, Marglit T, Eismann E, Lancet D, Kaupp B (1990) Primary structure of a cAMP-gated channel from bovine olfactory epithelium. FEBS Lett 270:24-29.

Maue RA, Dionne VE (1987) Preparation of isolated mouse olfactory receptor neurons. Pfluegers Arch 409:244-250.

Menco BPM (1984) Ciliated and microvillous structures of rat olfactory and nasal respiratory epithelia. Cell Tissue Res 235:225-242.

Menco BPM (1985a) Genesis of cilia and microvilli of rat nasal epithelia during pre-natal development. J Cell Sci 78:283-310.

Menco BPM (1985b) Genesis of cilia and microvilli of rat nasal epithelia during pre-natal development. J Cell Sci 78:311-336.
Miyamoto T, Restrepo D, Cragoe EJ, Teeter JH (1992) IP $_{3}$ and cAMPinduced responses in isolated olfactory receptor neurons from the channel catfish. J Membr Biol 127:173-183.

Nakamura T, Gold GH (1987) A cyclic-nucleotide gated conductance in olfactory receptor cilia. Nature 325:442-444.

Noble M, Mallaburn PS, Klein N (1984) The growth of olfactory neurons in short-term cultures of rat olfactory epithelium. Neurosci Lett 45:193-198.

Pace U, Hanski E, Salomon Y, Lancet D (1985) Odorant-sensitive adenylate cyclase may mediate olfactory reception. Nature 316:255258.

Pixley SK (1992) CNS glial cells support in vitro survival, division, and differentiation of dissociated olfactory neuronal progenitor cells. Neuron 8:1191-1204.

Pixley SK, Pun RYK (1990) Cultured rat olfactory neurons are excitable and respond to odors. Dev Brain Res 53:125-130.

Restrepo D, Boyle AG (1991) Stimulation of olfactory receptors alters regulation of [calcium] increases in isolated olfactory receptor neurons retaining their original spatial relationship in intact tissue. $\mathrm{J}$ Membr Biol 120:223-232.

Restrepo D, Miyamoto T, Bryant BP, Teeter JH (1990) Odor stimuli trigger influx of calcium into olfactory neurons of the channel catfish. Science 249:1166-1168.

Restrepo D, Teeter JH, Honda E, Boyle AG, Marecek JF, Prestwich GD, Kalinoski DL (1992) Evidence for an InsP ${ }_{3}$-gated channel protein in isolated rat olfactory cilia. Am J Physiol 263:C667-C673.

Ronnett GV, Hester LD, Snyder SH (1991a) Primary culture of neonatal rat olfactory neurons. J Neurosci 11:1243-1255.

Ronnett GV, Parfitt DJ, Hester LD, Snyder SH (199lb) Odorantsensitive adenylate cyclase: rapid potent activation and desensitization in primary olfactory neuronal cultures. Proc Natl Acad Sci USA $88: 2366-2369$.

Ronnett GV, Cho H, Hester LD, Wood SF, Snyder SH (1993) Odorants differentially enhance phosphoinositide turnover and adenylyl cyclase in olfactory receptor neuronal cultures. J Neurosci 13:17511758.

Salet C, Moreno G, Vinzens F (1983) Effects of photodynamic action on energy coupling of $\mathrm{Ca}^{2+}$ uptake in liver mitochondria. Biochem Biophys Res Commun 115:76-81.

Sibley DR, Benovic JL, Caron MG, Lefkowitz RJ (1987) Regulation of transmembrane signaling by receptor phosphorylation. Cell 48 : 913-922.

Sklar PB, Anholt RRH, Snyder SH (1986) The odorant-sensitive adenylate cyclase of olfactory receptor neurons. J Biol Chem 261:1553815543.

Suzuki N (1989) Voltage- and cyclic nucleotide-gated currents in isolated olfactory receptor cells. Chem Senses 14:469-493.

Zufall F, Hatt H, Firestein S (1993) Rapid application and removal of second messengers to cyclic nucleotide-gated channels from olfactory epithelium. Proc Natl Acad Sci USA 90:9335-9339. 